\title{
Information and Communication Technology (ICT) Implementation in Malaysian Political Parties
}

\author{
Raja Ahmad Iskandar Raja Yaacob, Abdul Mutalib Embong, Mohd Nuri Al Amin Endut, and \\ Abdur-Rahman Mohamed Amin
}

\begin{abstract}
The ICT implementation has been widely mentioned in many sectors such as education, government and business. However the implementation of ICT in political parties is rarely highlighted compared to the study from the political science view. This paper highlighted some preliminary study and interesting findings about ICT implementation of a case study in one of the dominant Malay political parties in Malaysia namely Islamic Party of Malaysia (PAS). It assessed the current level of ICT implementation as well as captured the requirement and future plan in the implementation of ICT in the political parties. It used observation, questionnaires and interviews on 14 respondents. There were five factors involved namely party and model, culture, social and organisational issues, ICT support and ICT impact and barriers. At the end, it was found that the party applied a systematic framework in ICT implementation in order to take advantages of ICT as a tool for spreading political message and program to the voters.
\end{abstract}

Index Terms-ICT implementation, Malaysian political parties, PAS.

\section{INTRODUCTION}

Information Communication Technology (ICT) include satellite broadcasting networks, television, video, digital radio, internet, extranets, wireless communication devices such as the mobile phone, video, digital video disks (DVDs), CD-ROM, and voicemail [1]. All of these technologies can contribute to a faster flow of information globally when linked into the digital information network. The ICT implementation has been widely deployed in education, government and business and has brought tremendous impact to these types of organisations. These implementations could be seen from the adaptation of e-learning, e-government and e-commerce applications [2]. Recently, ICT starts to be recognised as one of the critical success factors for political survival [3]. Parties' websites are the first gateways to access to the information about the party especially for the members of the parties and the prospective voters. In Indonesia, Parti Keadilan Sejahtera (PKS) has been extensively adapted ICT to maximise the efficiency of its organisational management and external objectives to the prospective voters. This could be seen from their website at http://www.pk-sejahtera.org. It adopted ICT to the extent that the prospective voters could be a party member by online registration and this approach is not

Manuscript received July 3, 2013; revised September 22, 2013

Raja Ahmad Iskandar Raja Yaacob, A. M. Embong, and Mohd Nuri Al Amin Endut are with the Universiti Teknologi Petronas, Sri Iskandar, Perak 31750 Malaysia_(e-mail:Iskandar_yaacob@petronas.com.my, urrahman_amin@petronas.com.my, Mutalib_embong@petronas.com.my, nuriend@petronas.com.my). yet implemented in Malaysia. Given that, this paper provides a preliminary case study on how Islamic Party of Malaysia (PAS), as one of Muslim dominant parties in Malaysia, incorporates ICT into their organizations.

\section{LITERATURE REVIEW}

There are numerous ways how political party adapt ICT in their organisation. In general, the literature distinguishes between at least four different primary party goals: vote maximization, office maximization, representation of members and policy or ideology advocacy [4]. Parties could use the ICT especially the Internet to provide more opportunities for participation, mobilisation and more information for ordinary members and closer contact between leader and the party grassroots [5]. During the Malaysian general Election 2004, various political parties that embarking the participation for the seats are rounding the campaign mostly through ICT. They use various tools such as Short Message Messenger (SMS), mobile phone, emails, video clips, teleconference, yahoo messenger besides electronic media such television or radio. These entire medium are heavily used by the parties to disseminate information and manifesto to the voters.

Besides election, most of the political parties now are fully equipped with the latest version of ICT tool in managing their party. By having websites for example have made the party management more effective in revealing any information or instruction for the party. Certain new effort by having on-line members' registration for the party also will enhance the participation of the people in the political activities. For the office bearing, through ICT, the party management will be more efficient in terms of disseminating instruction by the head quarter to all states, division and members. The communication will be more robust and can save a lot of time and money.

The Islamic Party of Malaysia (commonly known as PAS), is an Islamist political party in Malaysia. PAS positions itself as an Islamist party that aims to establish Malaysia as an Islamist country based on Islamic legal theory as opposed to Barisan Nasional's Malay supremacy. The party enjoys strong support from northern rural and conservative area such as Kelantan and Terengganu. It is also the first opposition party in independent Malaysia's history to defeat the Barisan Nasional coalition in a Malay dominated state. It has approximately 1.5 million members. In the early stage of ICT implementation in 1996, it was initially carried out by the PAS Youth Wing. However, realising the importance of ICT impact to the organisation, it has been upgraded to ICT 
Bureau which covers all the ICT policy-making, planning and implementation to the party [6].

Malaysia is a constitutional monarchy, lead by the King (Paramount Ruler) called as Yang Di Pertuan Agong. The King is also the head of the Islamic faith in Malaysia. And the government is a based on the parliamentary democracy. Malaysia is practicing the multi-party system that encourages its people to participate for their right. Meaning that the constitution recognized its people right through any political parties or even they can contest as individual candidate. Malaysia is a federal parliamentary democracy based on the Westminster model. The model is having the democratic system of governing [7]. The system is captured before Malaysia gets its independent from Britain in 1957, since then, as a commonwealth countries, most of the system are commonly adopted from it. National Front (Barisan Nasional ( $\mathrm{BN}$ ) is a confederation of 13 political parties dominated by the United Malays National Organisation (UMNO), Malaysian Chinese Association (MCA), Malaysian Indian Congress (MIC) and Gerakan Rakyat Malaysia (Gerakan) [8]. BN is a political coalition in Malaysia formed in 1973, others members of the Barisan Nasional are comprise from another 11 parties.

The alternative front or Barisan Alternatif (BA) is a coalition of Malaysian opposition parties. The pact is lead by the Pan-Islamic Party of Malaysia (PAS) together with Democratic Action Party (DAP), People Justice Party (PKR) and Malaysia People Party (PRM). Malaysia is a practice democratic country, which means anybody have their right in the process of democracy. Anybody can contest for the election which is held every five-year term, either individually or by group as political parties. [9]. There are 222 parliamentary seats for the House of Representative and 576 state legislature seats for the State Legislature Assembly to be contested.

The election will be conducted by Election Commission which is an independent body whose members are appointed by the King with consultation from the Conference of Rulers. The members are one chairman, one deputy chairman and three ordinary members [10]. Their duties are to decide on date for nomination day and Election Day. Besides that they have to arrange the registration of the voters and prepare electoral roll. Other scope is to determine election boundaries / constituencies, set election regulations, register candidates on nomination day and count votes and declare results

When the party launched its websites in 1998, the development of ICT became more important and vital. Based on online polling feedback, the huge response reflected the success of the websites, and coincidentally the increase of votes during 1999 Malaysia General Election. The response was the main motivating factors for the researchers to explore on the role of ICT. Due to time constrains, the researchers will only focus on the ICT development and social cultural context of Malaysian political parties.

ICT has become a national and government agenda in Malaysia, providing a new set of tools that can add value to traditional information systems. The Malaysian success in the next century hinges upon the infantile stage in IT knowledge [11]. By emphasizing the importance of research and development, innovation and creation and knowledge workers, these will be as the main elements to become a developed country.

Another aspect is to study ICT implementation between the two Malay dominant political parties in Malaysia. UMNO is the biggest ruling party in Malaysia, although Malaysian political system stated that the election were run under the name of National Coalition (BN), but UMNO is the backbone of $\mathrm{BN}$ and the ruling government. By focusing the ICT development in UMNO, it will show the level of ICT development for the coalition party and the government. UMNO also should be the drawing line for the ICT development within the political parties.

The freedom of expression in Malaysia is believed to be only for those who support the ruling government. The limitation of sharing prime information medium such as electronic or printed media from the opposition has driven the opposition parties in Malaysia to find alternative means to disseminate information to the people. Since, the opposition are having a hard time to convey their information to their members and public as a whole, but with some limitation, they manage to spread and conveying their mission and vision by using ICT. This effort done by the opposition has shown the grisp when they won in majority seats in the government of the state of Kelantan. With limited freedom in the dissemination of information, PAS specifically turned to IT to spread information to the people.

Therefore, the objectives of this research are to determine ICT knowledge, implementation and support available within the two major parties in Malaysia, namely PAS and $\mathrm{UMNO}$ in their political missions.

\section{Methodology}

In order to capture the requirement and asses the current ICT implementation in this case study, we adopt a slightly modified version of a roadmap called roadcon [12] from construction industry as a model. Even though the model is taken from a model for construction industry, this model is used as it has similar characteristics with political party in giving equal consideration to people, processes and technology. In this model, five areas have been identified to capture, assess and plan the ICT implementation of the political parties, namely: (1) party and model (2) culture, social and organisational issues, (3) ICT support, (4) ICT impact, and (5) barriers. Also included are the barriers faced by the political parties in its steps towards ICT implementation.

This is a preliminary study consists of assessing ICT implementation in PAS. In the future, we plan to study the ICT implementation in UMNO and provide the comparison between two parties. However, we still provide the background information about UMNO.

A total of 14 respondents are chosen for questionnaire and two respondents for the interview. The respondents are chosen those from the same level of position who held a post of the ICT secretary position. These respondents are the core ICT staff within the department / branches and have substantial information for the research questions.

Data was collected and analysed manually due to small numbers of respondent using open ended questionnaire and 
interview. It was divided into four main categories which is party and model, ICT support, ICT anticipated impact and barriers.

\section{RESUlTS AND DISCUSSION}

Table I provides early observation on the use of ICT implementation in UMNO and PAS.

TABLE I: COMPARISON ON EARLY OBSERVATION OF ICT IMPLEMENTATION IN UMNO AND PAS

\begin{tabular}{|l|c|c|}
\hline $\begin{array}{l}\text { Item } \\
\text { Political } \\
\text { Parties }\end{array}$ & UMNO & PAS \\
\hline $\begin{array}{l}\text { Financial } \\
\text { Support }\end{array}$ & Strong & Moderate \\
\hline $\begin{array}{l}\text { Human } \\
\text { Resources }\end{array}$ & $\begin{array}{c}\text { Paid Employee } \\
\text { Outsource }\end{array}$ & Voluntary basis \\
\hline $\begin{array}{l}\text { Media (TV) } \\
\text { Fully coverage }\end{array}$ & $\begin{array}{l}\text { Very limited } \\
\text { coverage }\end{array}$ \\
\hline ICT & $\begin{array}{c}\text { http://www.umn } \\
\text { o-online.com/ }\end{array}$ & $\begin{array}{l}\text { http://www.par } \\
\text { ti-pas.org.my }\end{array}$ \\
\hline
\end{tabular}

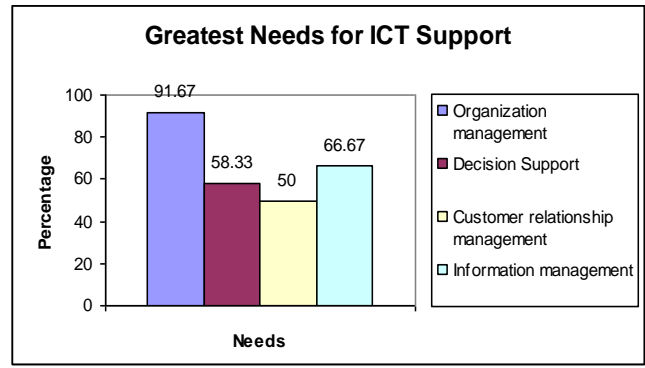

Fig. 1. Greatest needs for ICT support.

Fig. 1 shows that organization management is the greatest need for ICT support within the party however decision support system; customer relationship management and information management are the other important section that needs support from ICT because it suits with the evolution of management during current times when ICT is the fastest and accurate mode of storing and managing information.

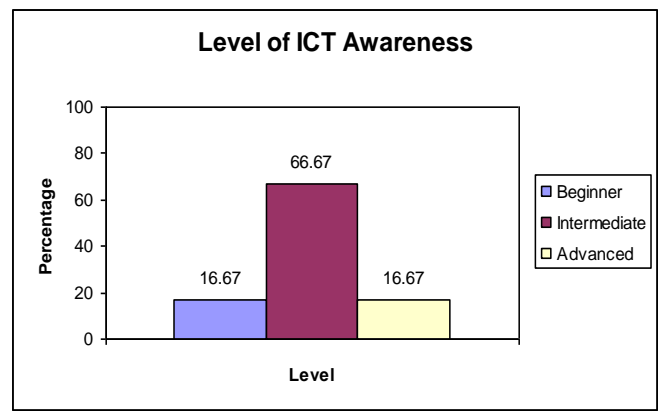

Fig. 2. Level of ICT awareness.

Fig. 2 shows that the level of ICT awareness in the party is average and only 16.67 percent for level of beginner and advanced. This could be done to party members' lack exposure in ICT since they are used to conventional print and electronic media such as television and radio only.

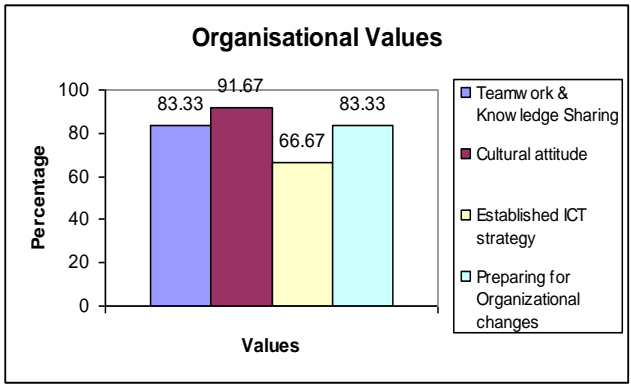

Fig. 3. Organisational values.

Fig. 3 above shows that ICT implementation has the highest impact on cultural attitude in organisational value. It also has a high percentage on teamwork, knowledge sharing and as a preparation for the changes

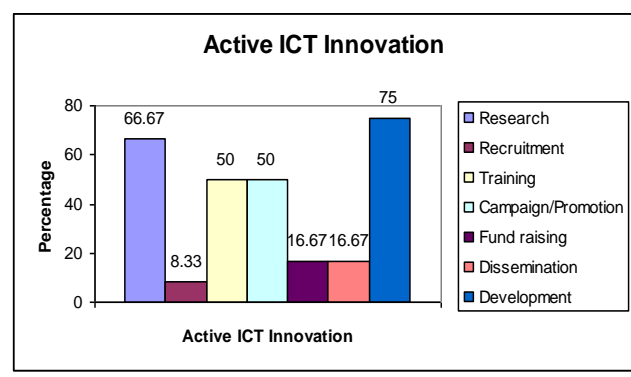

Fig. 4. Active ICT innovation.

Fig. 4 shows that the respondents believed that ICT innovation can be used for research and development as the highest. Training and promotion comes second and recruitment, fund raising and dissemination also can be used.

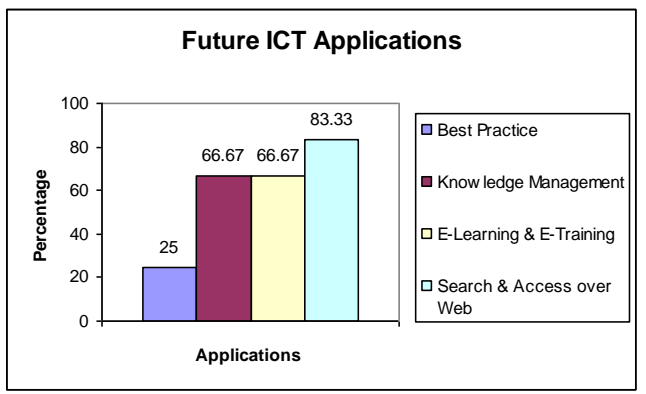

Fig. 5. Future ICT applications.

Fig. 5 shows the expected future ICT applications. The highest percentage is in applications on searching and access over web. The second highest ICT applications are in E-Learning and Knowledge Management. However the lowest percentage of ICT application is in the best practice. The respondents were of the opinion that best practice, knowledge management, E-learning and e-training and search and access over web could benefit from ICT application.

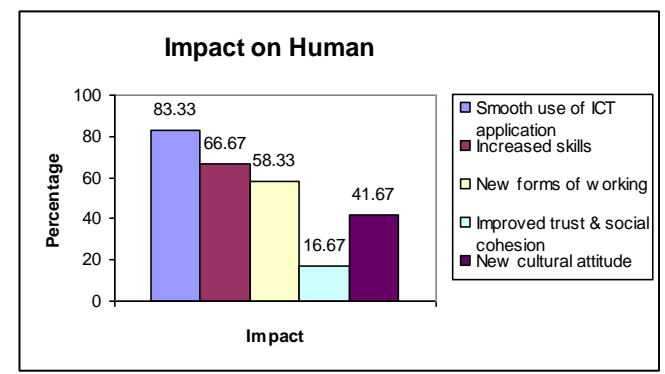

Fig. 6. Impact of ICT on human. 
Fig. 6 shows that smooth use of ICT application are the main impact on human by ICT. The other impact that shows by the graph are increased skills, new form of working, improved trust and social cohesion and new cultural attitude.

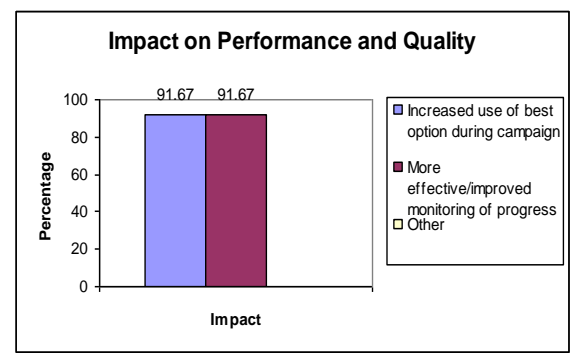

Fig. 7. Impact of ICT on performance and quality.

Fig. 7 shows that the respondents were aware that ICT can increased use of best option during campaign and become more effective in monitoring any progress.

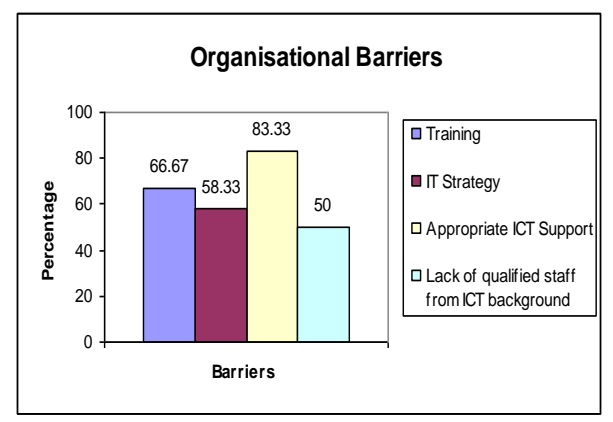

Fig. 8. Organisational barriers.

Fig. 8 shows that appropriate ICT infrasturture is the main organisational barrier for the party. Among the factors considered as organisation barriers in using ICT within the party are training, IT strategy, appropriate ICT support and lack of qualified staff from ICT background.

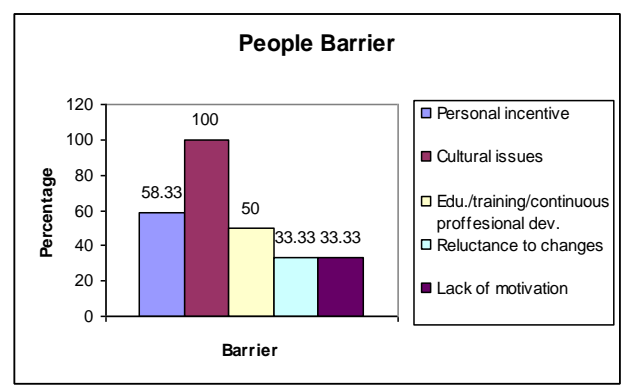

Fig. 9. People barriers.

Fig. 9 shows the cultural issue is the main people barrier of the party. Personal incentive and educational issues also can be considered as part of the main people barrier. Reluctant to change and lack of motivation also considered as the people barrier for the party

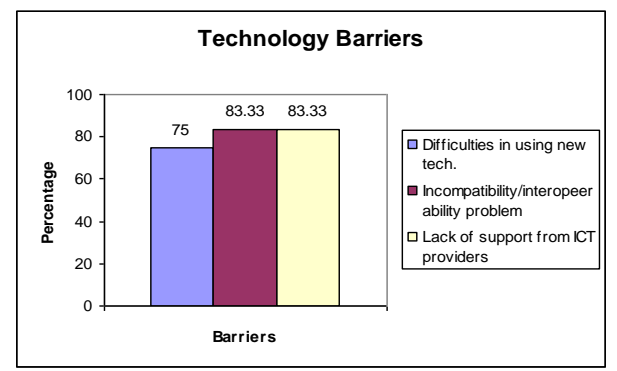

Fig. 10. Technology barriers.
Fig. 10 shows technology barriers in ICT implementation. It shows that the party faced two main technological barriers; incompatibility problem, ill-trained staff and lack of support from ICT providers including support from IT Department. Difficulties in using new technology are another technological barrier that has been faced by the party.

The highest ICT requirement in this party is in the organisation management and information management. Another important finding is that this party has a high requirement to recruit new ICT staffs and build ICT infrastructure in order to improve ICT implementation.

From the culture, social and organisational issue, the level of ICT awareness in PAS is at the average level. It shows that action and proper planning is needed to increase the ICT awareness in order to make the ICT implementation successful. So that this party would be able to grab the political advantage as well as minimise the resistance to change if the ICT awareness among the members is high.

The study also shows that ICT has the highest impact as the best option during campaign and more effective and improve monitoring progress of the party. This is indeed a significant finding since the young generation is widely exposed to the use of the Internet, WebTV and Web Radio which are an effective medium to deliver campaign manifesto effectively to the grass roots. Besides it shows that ICT can be used as a tool to monitor party progress in term of newly registered members, effective members' registration and monitoring the progress of the party branches.

Despite the lack of IT support in the party and minimum personal incentive received in terms of salary, the staffs possess a very high motivation and commitment in performing their job responsibilities. This is indeed a value-added and unique advantage for the party to achieve its ICT implementation.

However the party should take into consideration and proper action to overcome the lack of ICT support in the organisation. The highest barrier in the party is the cultural issues that will slow the progress of the party. PAS should look into the cultural issues because it is the main barrier. The party should come out with a proper strategy to promote positive values towards adopting new technology and optimise ICT to gain political advantage in the future.

\section{CONCLUSION}

This preliminary study provides an insight and early guidelines towards a better ICT implementation in political parties in Malaysia. This study implies the importance of political party in Malaysia to strengthen and fully utilize the using of ICT in their daily operation. This study also suggests that a clear policy and framework regarding ICT implementation should be implemented in the near future. The party management should financially support and allocate specific budget for ICT and personal incentive to be given to the pertinent staff. It is recommended that the next step of this study is to make a comparison between UMNO and PAS in ICT implementation to see the effectiveness of utilising it between these two dominant Malay parties in Malaysia. 


\section{REFERENCES}

[1] ICMOD

[Online].

http://www.icimod.org/focus/ict/ict-basic.htm

[2] O. Alina, "ICT in politics: From peaks of inflated expectations to voids of disillusionment," European Journal of E-Practice, no. 9 Mac 2010.

[3] W. Stephen, "New politics and the new media: Green parties, intra-party democracy and the potential of the Internet (an Anglo-Dutch Comparison)," with Gerrit Voerman, in Gerrit Voerman and Paul Lucardie (eds), Dutch Political Parties Yearbook, Groningen: University of Groningen, 2000.

[4] S. Kaare, "A behavioral theory of competitive political parties," American Journal of Political Science, vol. 34, pp. 565-98, 1990.

[5] R. Andrea, "Political parties, party communication and new information and communication technologies," Party Politics, Sage Publications, London, vol. 9, no. 1, pp. 7-20, 2003.

[6] JITP, "PAS: ICT policy and Strategy," PAS IT Convention, 2003.

[7] H. Matti et al., "Deliverable D52 construction ICT roadmap," ROADCON Project - IST-2001-37278.

[8] Malaysia: Country Forecast: Country Condition, Political Risk Yearbook: Malaysia Country Forecast, Mac 2004, pp. 15-22.

[9] Malaysia: Country Forecast: Political Overview, Political Risk Yearbook: Malaysia Country Forecast, 2005, pp. 7-29.

[10] Political Business Monitor International, Political Outlook, Malaysia Business Forecast Report, $4^{\text {th }}$ Quarter, 2005, pp. 3-8, ch. 2.

[11] Vision 2020, PMO, 1996.

[12] Malaysia: Country Forecast: Political Framework, Political Risk Yearbook: Malaysia Country Forecast, Nov. 2004, pp. 59, pp. 20.

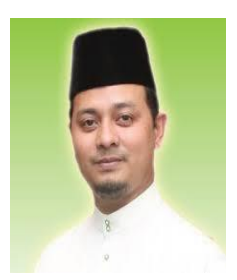

Raja Ahmad Iskandar Raja Yaacob was born in 1974 in Perak, Malaysia. He graduated from International Islamic University in 1998 in BHsc Political Science and obtained his MSc in Information Management from Universiti Teknologi Mara in 2000. He completed his PhD in Knowledge Management from the University of Manchester in 2011. He is actively doing his research in politics and information society. Currently he is a Senior Lecturer at the Department of Management and Humanities, Universiti Teknologi Petronas.

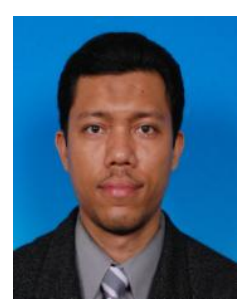

Abdur-Rahman Mohamed Amin was born in Terengganu, Malaysia in 1977. He graduated with a Bachelor of Arts (Hons) from International Islamic University Malaysia and a Master of Arts in Islamic Studies from University of Malaya in 2007. Currently he is a Lecturer at the Department of Management and Humanities, Universiti Teknologi Petronas, Bandar Seri Iskandar, Perak, Malaysia. His academic and research interests include the classical Jawi manuscript, biography of Muslim scholars in Southeast Asia and Malay intellectual history.

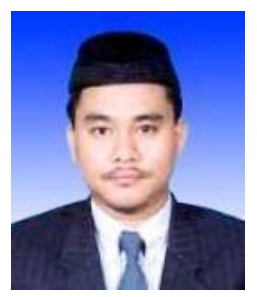

Mohd Nuri Al Amin Endut was born in Terengganu, Malaysia in 1969. He is currently a Senior Lecturer at the Department of Management and Humanities, Universiti Teknologi Petronas, Bandar Seri Iskandar, Perak, Malaysia. He obtained his $\mathrm{PhD}$ in Islamic Thought from University of Malaya, Malaysia early this year. He completed his Bachelor of Arts in Islamic and Arabic Studies from Al-Azhar University in Egypt and Master of Arts in Islamic Theology and Da'wah in AL al-Bayt Universiti in Jordan. His academic and research interests include Islamic Da'wah Movement in Malaysia, Islamic Critical Thinking, Islamic Science and Islamic Theology.

Abdul Mutalib Embong was born in 1970 in Kuala Lumpur, Malaysia. He graduated from Universiti Teknologi MARA in 1995 in Journalism and obtained his MSc in English Literiture from Universiti Pendidikan Sultan Idris in 2000. He is now pursuing his $\mathrm{PhD}$ at Universiti Teknologi PETRONAS . He is actively doing his research in language and linguistic. Currently he is a Lecturer at the Department of Management and Humanities, Universiti Teknologi Petronas. 